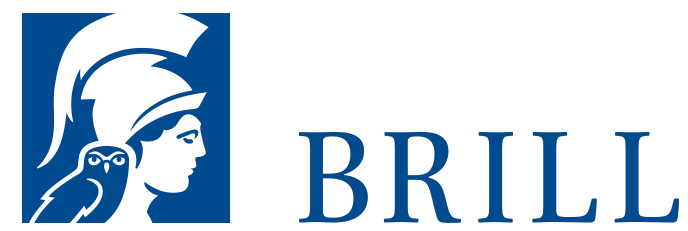

\title{
Studying the Historical Jesus
}

Evaluations of the State of Current Research

Authors: Bruce D. Chilton and Craig A. Evans

This volume offers critical assessments of Life of Jesus research in the last generation, with special emphasis on work that is quite recent. It will introduce graduate students to the field and will provide the veteran scholar with current bibliography and discussion of the issues.

Topics treated include Jesus and Palestinian politics, Jesus tradition in Paul, Jesus in extracanonical Gospels, and Jesus' parables, miracles, death, and resurrection.

The contributors are among the most widely recognized and respected Life of Jesus scholars. They include Marcus J. Borg, James H. Charlesworth, James D.G. Dunn, Sean Freyne, Richard Horsley, and Helmut Koester.

\section{Readership}

All those interested in Life of Jesus research, first-century Palestine, and the value of extracanonical sources for Life of Jesus research.

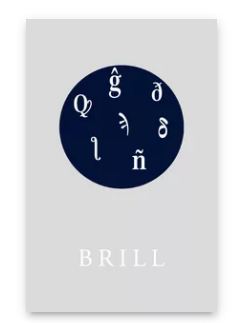

Pages: xvi, 611 pp.

Language: English

Subjects: New Testament \& Early Christian Writings, Biblical Studies Publisher: Brill

Series:

New Testament

Tools, Studies

and Documents,

Volume: 19

E-Book (PDF)

Released online: 26 Nov 2019

ISBN: 978-90-

o4-37989-3

List price

USD $\$ 220.00$

Hardback

Publication date: o1 Jun 1994

ISBN: 978-9004-09982-1 
Bruce Chilton, Ph.D. (1976) in Divinity, Cambridge University (St. John's College) is Bernard Iddings Bell Professor of Religion at Bard College. He is a scholar of early Christianity and Judaism; his publications include The Isaiah Targum (Clark and Glazier, 1987) and The Temple of Jesus (Penn. State, 1992).

Craig A. Evans, Ph.D. (1983) in Religion, Claremont Graduate School, is Professor of Biblical Studies at Trinity Western University in Langley, British Columbia, Canada. He has published extensively on Jesus and the Gospels, including Life of Jesus Research: An Annotated Bibliography (Brill, 1989).

For more information see brill.com

Order information: Order online at brill.com +44330 333 0049 | customerservices@brill.com Submission information: brill.com/authors

Titles published by Brill | Fink, Brill | mentis or Brill | Schöningh: +49(o)71 5413279216 | brill@brocom.de 